\title{
ANATOMICAL STUDY OF THE ABDOMINAL AORTA SACRAL RAMI OF THE OPOSSUM (Didelphis albiventris).
}

\author{
ESTUDIO ANATÓMICO DE LOS RAMAS SACRALES DE LA AORTA ABDOMINAL DE LA COMADREJA OVERA (Didelphis albiventris)
}

\author{
José Ricardo de Carvalho Pinto e Silva \& Márcia Regina Fernandes Boaro Martins
}

PINTO E SILVA, C. J. R. \& MARTINS, B. M. R. Anatomical study of the abdominal aorta sacral rami of the opossum (Didelphis albiventris). Int. J. Morphol., 22(3):217-220, 2004.

SUMMARY: The objective of this study was to describe the anatomy of the opossum abdominal aorta sacral rami, emphasizing the common iliac arteries, external and internal iliac arteries and the middle sacral artery.

Ten animals Didelphis albiventris from the Department of Anatomy, Instituto de Biociências - UNESP Botucatu, were used. After laparotomy, the aorta and its terminal rami were seen, dissected under microscopy and photographed.

The abdominal aorta emitted rami, forming the right and the left common iliac arteries that divided, originating the external and internal iliac arteries. The middle sacral artery presented in $30 \%$ of cases now caudally rising from the right common iliac artery, then from the left one (30\%) or in most cases (40\%), as a continuation of the abdominal aorta artery.

KEY WORDS: 1. Anatomy; 2. Opossum; 3. Aorta.

\section{INTRODUCTION}

The opossum, one of the most primitive mammals, has been studied in its macroscopic aspects. Taking in account the need to understand its biological functions, this work aimed at obtaining data to contribute to a better understanding of its anatomy and the iliac and sacral artery sistematization.

Orsi et al. (1976) stated that the internal pudendal artery in the rabbit (Oryctolagus cuniculus) is the continued common iliac artery.

Orsi et al. (1977) and Abreu et al. (1979) carried out a comparative study on the pelvic arterial vascularization of laboratory mammals, rabbit and guinea pig, describing the terminal rami with two common iliac arteries.

Favre (1967), however, studying the guinea pig arterial system, concluded that the aorta ends in the same way it occurs in hamster and man, where the middle sacral artery emerges from and the external and internal iliac arteries bifurcate.

Perneczky (1969), Stump \& Shively (1976) and Vicentini et al. (1981) also studied guinea pig, showing the terminal aorta bifurcation giving off the iliac arteries.
According to Greene (1963) and Farris \& Griffith (1963), in rats the arteries are aorta terminal rami and the common iliac artery ramification is variable.

Arruda (1922) studied the armadillo, describing that after the bifurcations which originate the external and internal iliac arteries, the aorta runs like middle sacral artery, giving off small vessels.

\section{MATERIAL AND METHOD}

Ten animals Didelphis albiventris from the Department of Anatomy, Instituto de Biociências - UNESP Botucatu, were used.

Neoprene latex 450 colored with red pigment was introduced into the common carotid artery of the animals which were then immersed in 10\% formaldehyde solution for fixation. After laparotomy, the aorta and its terminal rami were seen, dissected under microscopy and photographed. 


\section{RESULTS}

The aorta was found along with the ventral surface of lumbar and sacral vertebrae, dorsally to the colon, following the caudal vena cava to the right, with the Psoas major, Psoas minor and Quadratus lumborum. Along the fifth lumbar vertebra, the aorta presented a different diameter, dividing into a right and a left common iliac artery in all cases (Fig. 1).

The common iliac artery with caudal and lateral direction was divided, originating the external iliac artery, main artery of the posterior limb, which continued obliqually to become femoral artery and an internal iliac artery always with smaller diameter to reach the surrounding organs (Fig. 1).

The middle sacral artery, however, arose now from the right common iliac artery in $(30 \%$ of cases), then from the left one $(30 \%$ of cases) and in $40 \%$ of cases, it presented caudally continued the abdominal aorta. In all preparations regardless the site the middle sacral artery arose from, it presented up to 3 dorsal sacral rami (Fig. 1, 2, 3, 4).

\section{DISCUSSION}

As for the abdominal aorta division, forming two common iliac arteries, some divergences with some authors were observed.

According to Arruda, only some samples $(40 \%)$ presented the common iliac artery different from what was described by Favre, Orsi et al. (1977) and Abreu et al. in guinea pig and rabbit, and in rat and man by Greene, who stated that such artery presence was constant, showing a pattern of normality, which corroborates with our findings.

The external and internal iliac arteries were observed in guinea pig by Vicentini et al. and in rat by Greene and Farris \& Griffith, similarly to our study, that is, an aorta artery emitting the common iliac arteries and from these ones the external and internal iliac arteries originate.

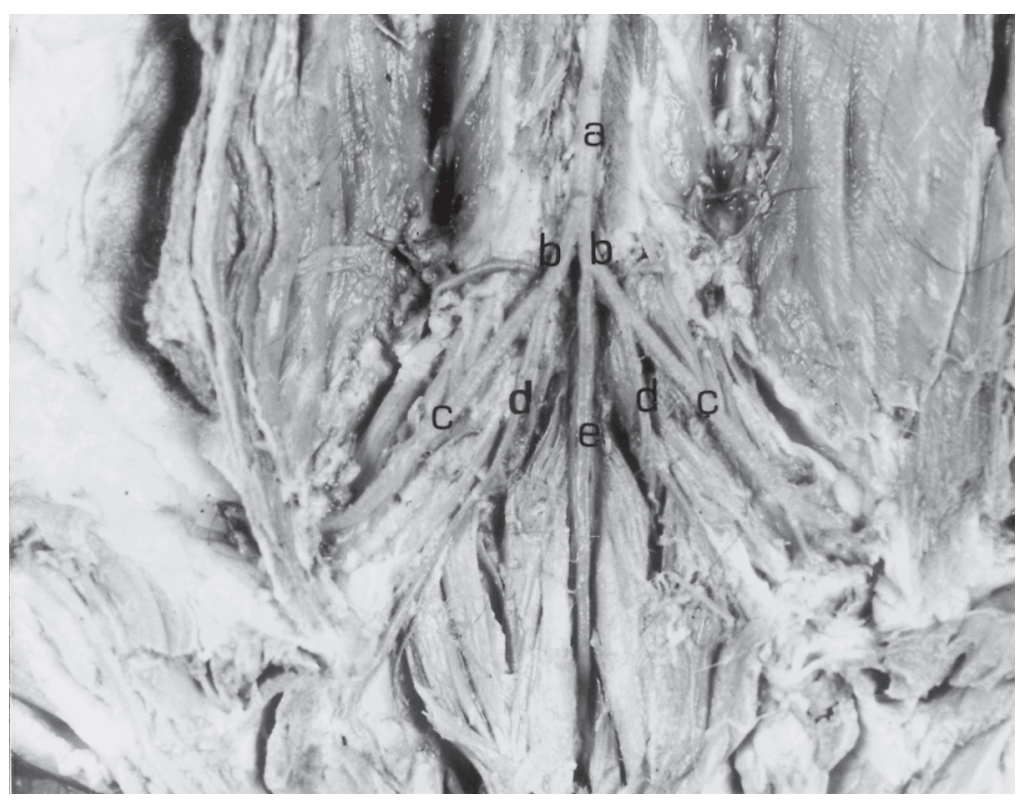

Fig. 1.Ventral view, evidencing the aorta artery (a) distributing the common iliac artery (b), external iliac artery (c), internal iliac artery (d) and middle sacral artery (e).

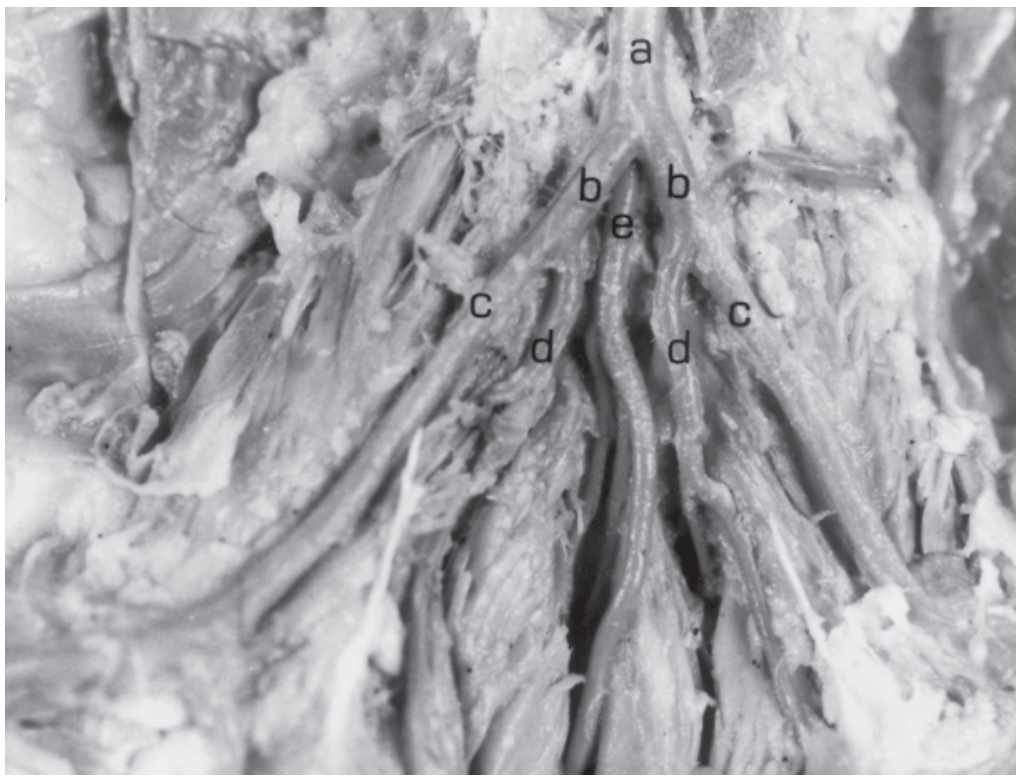

Fig. 2. Ventral view, evidencing the middle sacral artery (e) originating straightforward from the aorta artery (a), common iliac artery (b), external iliac artery (c), internal iliac artery (d).

Studying laboratory animals, Orsi et al (1977), Abreu et al. and Vicentini et al. stated that the middle sacral artery originated from the aorta dorsal side, similarly to Favre, who concluded that it originated from the aorta among the common iliac arteries, and Perneczky, who stated that it emmerged dorsally from the aorta terminal portion like a single vessel, showing this way an equality of pattern in $40 \%$ of our findings, however, not in the other presentations where it was found now from the common iliac artery, then from the left one. 


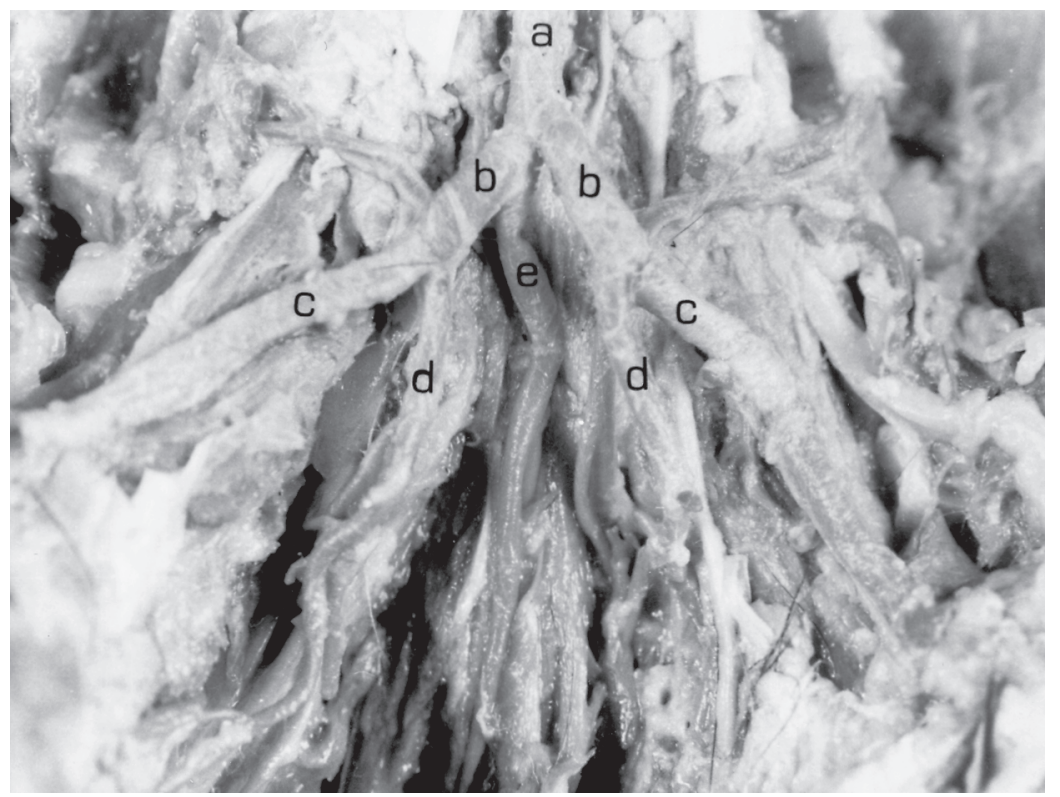

Fig. 3. Ventral view, evidencing the middle sacral artery (e) originating from the right common iliac artery (b), aorta artery (a), external iliac artery (c), internal iliac artery (d).

Fig. 4. Ventral view, evidencing the middle sacral artery (e) originating straight forward from the left common iliac artery (b), external iliac artery (c), internal iliac artery (d).

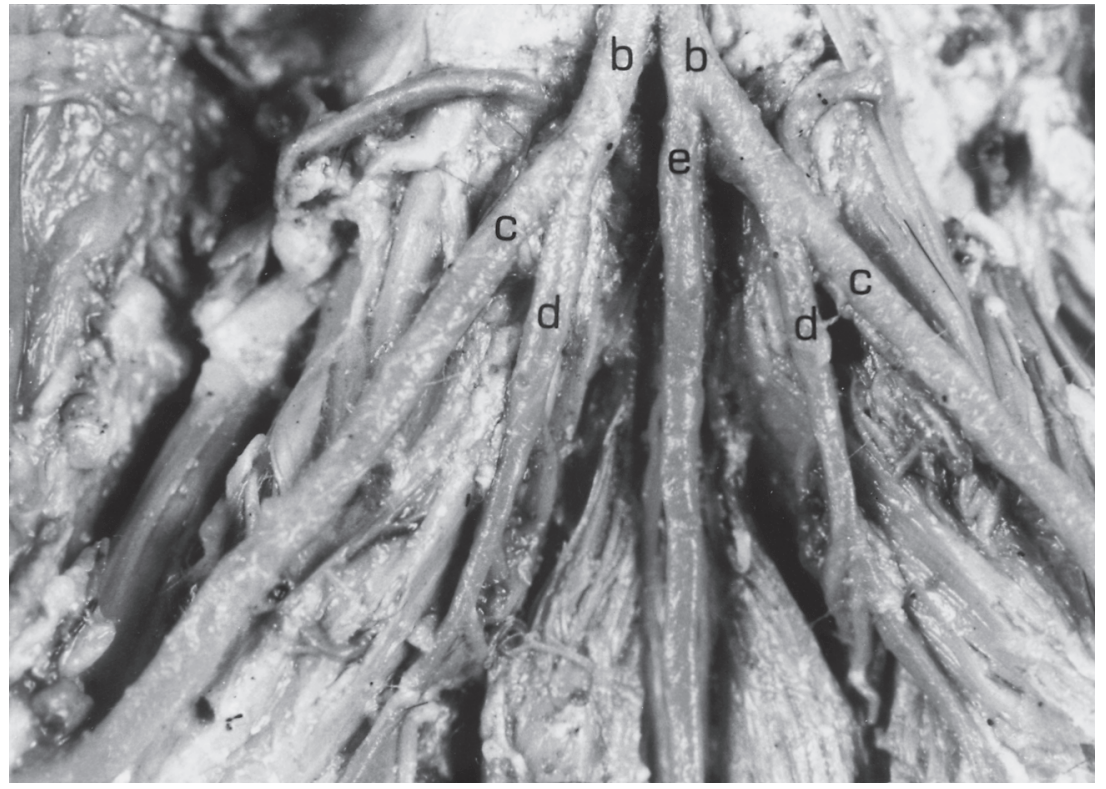

PINTO E SILVA, C. J. R. \& MARTINS, B. M. R. Estudio anatómico de los ramas sacrales de la aorta abdominal de la comadreja overa (Didelphis albiventris). Int. J. Morphol., 22(3):217-220, 2004.

RESUMEN: El objetivo de este estudio fue describir la anatomía de la aorta abdominal de la comadreja overa (Didelphis albiventris) enfatizando las arterias iliacas comunes, las arterias iliacas interna y externa y la arteria sacra mediana.

Utilizamos 10 animales Didelphis albiventris del Departamento de Anatomía, Instituto de Biociencias - UNESP, Botucatú, Brasil. Después de la laparotomía fueron examinadas la aorta y sus ramas terminales, disecadas bajo microscopio y fotografiadas.

La aorta abdominal originó las arterias iliacas comunes derecha e izquierda, las cuales se dividen en las arterias iliacas externa e interna. La arteria sacra mediana se originó en el $30 \%$ de los casos de la arteria iliaca común derecha, en el $30 \%$ de la arteria iliaca común izquierda y en el $40 \%$ como una continuación de la aorta abdominal.

PALABRAS CLAVE: 1. Anatomía; 2. Opossum; 3. Aorta. 


\section{REFERENCES}

Abreu, M. A. F; Orsi, A. M. \& Mello Dias, S. Branches terminales de l'orte du lapin (Oryctolagus cunicullus). Arch. Anat. y Embriol., 44:141-6, 1979.

Arruda, O. S. Contribuição ao estudo anatômico das artérias e veias da região medial da coxa do tatu (Dasypus novemcinctus), Linnaeus, 1758). Botucatu, 56p. Dissertação (Mestrado) - Instituto de Biociências, Universidade Estadual Paulista, 1992.

Farris, E. J. \& Griffith, J. Q. J. The rat in laboratory investigation. 3.ed. New York, Hafner, 1963. 542p.

Favre, P. Contribution à l'étudedu système artériel du Cobaye (Abdomen, Bassin, Membre pelvien). Paris, 68p. Thèse (Doctorat Vétérinaire) - Ecole Nationale Veterinaire D’Alfort, Faculté de Medicina de Paris, 1967.

Greene, E.C. Anatomy of the rat. New York, Hafner, 1963. 370p.
Orsi, A. M; Pinto e Silva, P. \& Campos, V. J.M. Considerações sobre os ramos viscerais da artéria pudenda interna do coelho (Oryctolagus cunicullus). Rev. Fac. Méd. Vet. Zootec. Univ. São Paulo, 13: 459-63, 1976.

Orsi, A.M; Pinto e Silva, P. \& Fernandez, W. A. Estudio de los ramos de la aorta abdominal del hamster dorado Mesocricetus auratus. Arch. Anat. y Embriol., 12: 190203, 1977.

Perneczky, V. A. Die ästre de aorta abdominalis beis meerschweinchen. Anat. Anz., 125: 443-53, 1969.

Stump, E. J. \& Shively, M. J. The systemic arterial pattern of guinea pig: the pelvis and pelvic limb. Am. J. Anat. 147: 193-201, 1976.

Vicentini, C. A; Orsi, A.M. \& Silva, Z. et al. Comportamento anatômico das artérias umbilical (lig. redondo da bexiga) e urogenital na cobaia (Cavia porcellus, L., 1756). Rev. Fac. Méd. Vet. Zootec. Univ. São Paulo, 18: 15-7, 1981.
Correspondence to:

Prof. Dr. José Ricardo de Carvalfo Pinto e Silva

Departamento de Anatomia

Instituto de Biociências

Universidade Estadual Paulista-ULNESP

Botucatu, $S \mathcal{P}$,

BRASIL
Received: 08-06-2004

Accepted: 19-07-2004 